\title{
Increased levels of nitric oxide metabolites in urine from leprosy patients in reversal reaction
}

\author{
THOMAS SCHÖN*, NEGUSSIE GEBRE**, \\ TOMMY SUNDQVIST ${ }^{*}$, HAILE SELASSIE H/MARIAM ${ }^{\dagger}$, \\ TAYE ENGEDA ${ }^{\dagger} \&$ SVEN BRITTON ${ }^{* *}$ \\ *Department of Medical Microbiology, Faculty of Health Sciences, \\ Linköping University, Sweden \\ ${ }^{* *}$ Armauer Hansen Research Institute (AHRI), Addis Ababa, Ethiopia \\ ${ }^{\dagger}$ All Africa Leprosy And Rehabilitation Training Center (ALERT), \\ Addis Ababa, Ethiopia
}

\begin{abstract}
Accepted for publication 1 December 1998
Summary We measured the metabolites of $\mathrm{NO}$ [nitrite $\left(\mathrm{NO}_{2}^{-}\right)$and nitrate $\left.\left(\mathrm{NO}_{3}^{-}\right)\right]$in urine from Ethiopian patients suffering from leprosy. The urinary level of $\mathrm{NO}_{2}^{-} / \mathrm{NO}_{3}^{-}$ in a group of healthy Ethiopians was $1020 \pm 471 \mu \mathrm{M}(n=22)$. Leprosy patients in reversal reaction had significantly higher levels of $\mathrm{NO}_{2}^{-} / \mathrm{NO}_{3}^{-}(1817 \pm 492 \mu \mathrm{M}$, $p<0 \cdot 001, n=12)$ than both the control group and leprosy patients who were not in reversal reaction $(1079 \pm 446 \mu \mathrm{M}, n=12)$. We conclude that the reversal reaction in leprosy is associated with increased urinary levels of nitric oxide metabolites.
\end{abstract}

\section{Introduction}

Leprosy according to WHO definitions presently affects approximately 1 million individuals worldwide $^{1}$ and the disease primary involves the skin and peripheral nerve system. ${ }^{2}$ Leprosy is classified according to immunity as a polar disease with a spectrum ranging from the tuberculoid (TT) to the lepromatous (LL) form, with the borderline forms in between. ${ }^{3}$ The term 'reaction' in leprosy is used to describe the appearance of symptoms and signs of acute inflammation. Type 1 reversal reactions occurring in borderline cases are associated with an increase in cell-mediated immunity, and nerve damage from neuritis may be rapid and severe. ${ }^{2}$

Inducible NO synthase (iNOS) is responsible for the synthesis of NO and L-citrulline from L-arginine by activated macrophages. NO is highly unstable and decays to its stable end products nitrate $\left(\mathrm{NO}_{3}^{-}\right)$and nitrite $\left(\mathrm{NO}_{2}^{-}\right)$, which are eliminated in the urine. ${ }^{4}$ Evidence is accumulating that nitric oxide (NO) produced by macrophages is an important factor in host defence against intracellular pathogens such as M. tuberculosi ${ }^{5-7}$ and M. leprae. ${ }^{8,9}$ A recent 
report has described the presence of iNOS in skin biopsies from patients undergoing reversal reaction. ${ }^{10}$ The aim of this study was to investigate the urinary levels of nitric oxide metabolites in patients with leprosy in the reactional stage of the disease.

\section{Materials and methods}

MATERIALS

These were: Aspergillus nitrate reductase (Boehringer Mannheim, Freiberg, Germany), NADPH as the tetrasodium salt (Boehringer Mannheim), sulphanilic acid (Merck, Darmstadt, Germany), sodium nitrate (Merck), sodium nitrate (Sigma Chemical Co., St Louis, USA), $N$-(1-naphthyl) ethylenediamine (Sigma) and phosphate buffered saline (PBS).

\section{COLLECTION OF URINE SAMPLES}

Leprosy patients in the reactional stage were admitted to the wards of ALERT Hospital, Addis Ababa, Ethiopia because of reversal reaction in leprosy $[n=12$, males $=7$, females $=5$, average age $31 \pm 12$ years old, age range $14-54$, borderline lepromatous $(\mathrm{BL}=8)$, borderline tuberculoid $(\mathrm{BT}=4)$ ]. All patients were in reversal reaction (type I reaction) and were differentiated clinically from patients with erythema nodosum leprosum (type II reaction). The samples from these patients were obtained within 2 weeks after admission and all patients were on steroid treatment. The patients did not show clinical signs of any co-existing disease and all had negative stool samples by microscopy. Urine samples were also collected from 12 patients suffering from borderline forms of leprosy [borderline lepromatous $(\mathrm{BL}=2)$, borderline tuberculoid $(\mathrm{BT}=10)$ ] who were not undergoing reversal reaction (males $=5$, females $=7$, average age $38 \pm 14$ years old, age range 18-63). The control group for urinary levels of $\mathrm{NO}_{2}^{-} / \mathrm{NO}_{3}^{-}$consisted of 22 healthy Ethiopian individuals $(n=22$, males $=13$, females $=9$, average age $36 \pm 9$ years old, age range 20-55). All urine samples were morning urine samples and were stored at $-20^{\circ} \mathrm{C}$ until analysed. The study was approved by the ethical committee at Armauer Hansen Research Institute and ALERT Hospital, Addis Ababa, Ethiopia.

ANALYSIS OF NITRITE AND NITRATE

The sum of the $\mathrm{NO}_{3}^{-}$and $\mathrm{NO}_{2}^{-}$concentrations in urine was determined essentially as described by Giliam et al. ${ }^{11}$ Urine was diluted in PBS. Nitrate in the samples was reduced to $\mathrm{NO}_{2}^{-}$by incubating the sample with $10 \mu \mathrm{l}$ nitrate reductase from Aspergillus $(10 \mathrm{IU} / \mathrm{ml})$ and $10 \mu \mathrm{l}$ nicotinamide adenine dinucleotide phosphate (reduced NADPH; $1 \mathrm{mM}$ ) for $2 \mathrm{~h}$ at $37^{\circ} \mathrm{C}$. The $\mathrm{NO}_{2}^{-}$level was then determined by the Griess reaction. The final reaction volume of $1 \mathrm{ml}$ contained $728 \mu \mathrm{l} \mathrm{HCl}(0.45 \mathrm{M}), 86 \mu \mathrm{l}$ sulphanilic acid $(2 \mathrm{mg} / \mathrm{ml}), 86 \mu \mathrm{l} N$-(1-naphthyl) ethylenediamine $(1 \mathrm{mg} / \mathrm{ml})$ and $100 \mu \mathrm{l}$ of the diluted urine sample. The urine samples were then analysed on a ELISA multiwell reader (Titertec Multiscan Plus) at $542 \mathrm{~nm}$.

STATISTICAL ANALYSIS

Statistical evaluation was performed with the Mann-Whitney $U$-test for comparison between groups. Data are presented as mean $\pm \mathrm{SD}$. 


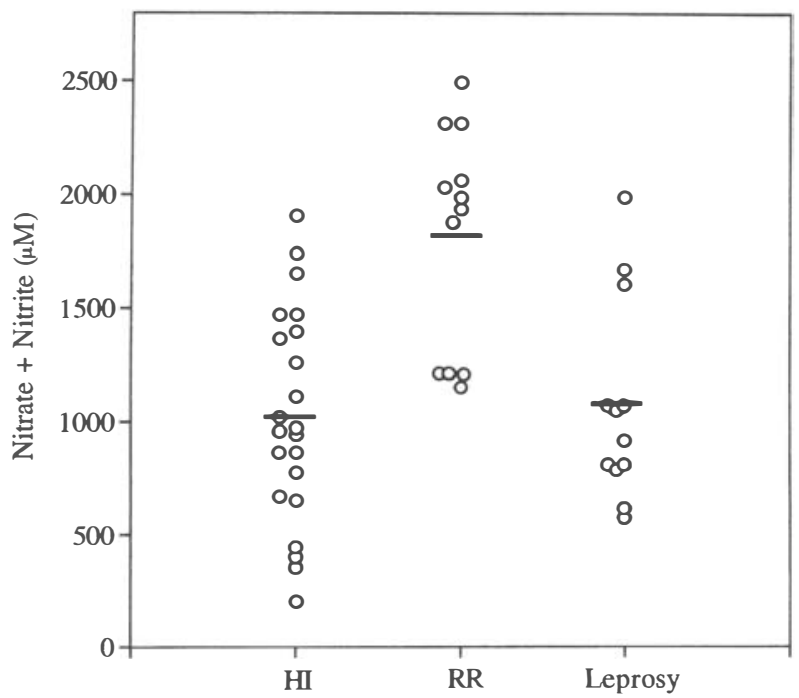

Figure 1. Urinary levels of nitrate and nitrite (the mean is represented by bold lines) in: healthy Ethiopian individuals $(\mathrm{HI}, n=22)$, leprosy patients in reversal reaction $(\mathrm{RR}, n=12)$ and leprosy patients who were not undergoing reversal reaction (Leprosy, $n=12$ ).

\section{Results}

The control group consisted of apparently healthy Ethiopian individuals. The mean urinary excretion of $\mathrm{NO}_{2}^{-} / \mathrm{NO}_{3}^{-}$in this group of 22 individuals was found to be $1020 \pm 471 \mu \mathrm{M}$ (range 198-1907) (Figure 1). Urine was obtained from leprosy patients admitted to the ALERT Hospital, Addis Ababa, Ethiopia because they were undergoing reversal reaction. Leprosy patients in reversal reaction had significantly higher levels of $\mathrm{NO}_{2}^{-} / \mathrm{NO}_{3}^{-}$ (1817 $\pm 492 \mu \mathrm{M}, p<0 \cdot 001, n=12$ ) than both the control group and leprosy patients who were not undergoing reversal reaction $(1079 \pm 446 \mu \mathrm{M}, n=12)$.

\section{Discussion}

Nitric oxide produced by the macrophage has been suggested to play an important role in the host response to pathogens targeting the macrophage such as $M$. leprae. ${ }^{10,12,13}$ The metabolites of $\mathrm{NO}, \mathrm{NO}_{3}^{-}$and $\mathrm{NO}_{2}^{-}$, have been used as a measurement of the production of NO in serum and urine from humans in various diseases such as cancer, ${ }^{14}$ malaria ${ }^{15}$ and children with coeliac disease. ${ }^{16}$ In humans the sources of $\mathrm{NO}_{2}^{-} / \mathrm{NO}_{3}^{-}$are food, air $\left(\mathrm{NO}_{2}\right)$ and endogenous synthesis, ${ }^{17}$ In this study, there were no restrictions of $\mathrm{NO}_{2}^{-} / \mathrm{NO}_{3}^{-}$in the diet in any of the study groups, and increases of $\mathrm{NO}_{2}^{-} / \mathrm{NO}_{3}^{-}$might be influenced by a diet rich in nitrate-containing food. However, in this study there was a strong correlation between increased levels of NO metabolites and the reactional stage of leprosy, where NO has been suggested to play a role in the host response. Our results are also consistent with a recent report where 13 out of 15 leprosy patients undergoing reversal reaction were iNOS positive in skin biopsies, whereas BT patients and healthy controls were completely negative. ${ }^{10}$ The 
reactional stage of leprosy is a stage of the disease associated with acute inflammation. ${ }^{2}$ Patients with ulcerative colitis, Crohn's disease and coeliac disease also have increased levels of nitrate and nitrite during active stages when the degree of inflammation is high, but normal levels of nitrate and nitrite between these stages. ${ }^{16,18}$ Thus, there seem to be a connection between NO production and acute inflammation. Further studies are required to evaluate raised levels of urinary NO metabolites as a predictive marker of reversal reactions in leprosy. We conclude that leprosy patients in reversal reaction have increased urinary levels of NO metabolites.

\section{References}

1 Editorial. Lepr Rev, 1997; 68: 195-200.

2 Gelber HG. Leprosy (Hansen's disease). In: Mandell GL, Bennet JE, Dolin R. Mandell, eds. Douglas and Bennett's principles and practice of infectious diseases. Churchill Livingstone, New York, 1995; 2243-2250.

${ }^{3}$ Ridley DS, Jopline WH. Classification of leprosy according to immunity. A five group system. Int J Lepr, 1966; 34: $255-273$.

4 Änggård E. Nitric oxide: mediator, murderer and medicine. Lancet, 1994; 343: 1199-1206.

${ }^{5}$ Chan J, Xing Y, Magliozzo RS, Bloom BR. Killing of virulent Mycobacterium tuberculosis by reactive nitrogen intermediates produced by activated murine macrophages. J Exp Med, 1992; 175: 1111-1122.

${ }^{6}$ Chan J, Tanaka K, Carrol D, Flynn J, Bloom BR. Effects of nitric oxide synthase inhibitors on murine infection with Mycobacterium tuberculosis. Infect Immun, 1995; 63: 736-740.

7 Nicholson S, Bonecini-Almeida M, Lapa e Silva JR, Nathan C, Xie Qiao-wen, Mumford R, Weidner JR, Calaycay J, Geng J, Boechat N, Linhares C, Rom W, Ho JL. Inducible nitric oxide synthase in pulmonary alveolar macrophages from patients with tuberculosis. J Exp Med, 1996; 183: 2293-2302.

8 Adams LB, Franzblau SG, Vavrin Z, Hibbs Jr JB, Krahenbuhl JL. L-Arginine-dependent macrophage effector functions inhibit metabolic activity of Mycobacterium laprae. J Immunol, 1991; 147: 1642-1646.

9 Khare S, Bhutani LK, Rao DN. Release of reactive nitrogen intermediates from the peripheral blood-derived monocytes/macrophages of leprosy patients stimulated in vitro by tuftsin. Lepr Rev, 1997; 68: 16-24.

${ }^{10}$ Khanolkar-Young S, Snowdown D, Lockwood DNJ. Immunocytochemical localisation of inducible nitric oxide synthase and transforming growth factor- $\beta$ in leprosy lesions. Clin Exp Immunol, 1998; 113: 438-442.

11 Giliam MB, Sherman MP, Griscavage JM, Ignarro LJ. A spectrophotometric assay for nitrate using NADPH oxidation by Aspergillus nitrate reductase. Anal Biochem, 1993; 212: 259-265.

12 MacMicking J, Xie Qiao-Wen, Nathan C. Nitric oxide and macrophage function. Annu Rev Immunol, 1997; 15: 323-350.

13 DeGroote MA, Fang FC. NO inhibitions: antimicrobial properties of nitric oxide. Clin Invest Dis, 1995; 21: S162165.

${ }^{14}$ Hibbs Jr JB, Westenfelder C, Taintor R, Vavrin Z, Kablitz C, Baranowski RL, Ward JH, Menlove RL, McMurry MP, Kushner JP, Samlowski WE. Evidence for cytokine-inducible nitric oxide synthesis from L-arginine in patients receiving interleukin-2 therapy. J Clin Invest, 1992; 89: 867-877.

15 Anstey NM, Weinberg JB, Hassanali MY, Mwaikambo ED, Manyenga D, Misukonis MA, Amelle DR, Hollis D, McDonald MI, Granger DL. Nitric oxide in Tanzanian children with malaria: inverse relationship between malaria severity and nitric oxide production/nitric oxide synthase type 2 expression. J Exp Med, 1996; 184: 557-567.

16 Sundqvist T, Laurin P, Fälth-Magnusson K, Magnusson K-E, Stenhammar L. Significantly increased levels of nitric oxide products in urine of children with celiac disease. J Pediat Gastroenterol Nutr, 1998; 27: 196-198.

17 Green LC, De Luzuriaga KR, Wagner DA, Rand W, Istfan N, Young VR, Tannenbaum SR. Nitrate biosynthesis in man. Proc Natl Acad Sci USA, 1981; 84: 6369-6373.

18 Oudkerk Pool M, Bouma G, Visser JJ, Kolkman JJ, Tran DD, Meuwissen SGM, Pena AS. Serum nitrate levels in ulcerative colitis and Crohn's disease. Scand J Gastroenterol, 1995; 30: 784-788. 